\title{
DMBA 乳腺腫瘍発生に及ぼすホルモン剂および
}

\section{免疫賦活剂の影響}

\author{
论飯野佑一，石川浩，吉田正男 \\ 泉雄勝, 滝川泱男* \\ 群馬大学医学部第二外科学教室 (主任: 泉雄 勝教授) \\ *群馬大学内分泌研究所薬学部門
}

(昭和60年12月19日 受付)

現在ホルモン剤および免疫賦活剤は, 乳癌の治療 に広く用いられている1 5).これら治療剤の発癌過程 に及ぼす影響については余り知られていない。そこ で著者らは7，12-dimethylbenz〔a〕-anthracene(以 下 DMBA）を投与した雌 Sprague Dawley（以下 SD) ラットを用いて乳癌の治療剤であるこれらホル モン剤および免疫賦活剤の DMBA 乳腺腫瘍発生過 程における抑制作用について検討した。

\section{対象および方法}

雌ラット 6 週齢 (体重 $150 \mathrm{~g}$ 前後) に対して発癌物

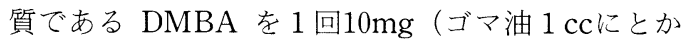
す) $\times 2$ 回 計 $20 \mathrm{mg}$ をgastric intubation にて強制 的に服用させた. DMBA 投与 1 週後より 12 週まで
ホルモン剤および免疫賦活剤をそれぞれ単独にて投 与した。投与量は臨床投与量を体重当りに換算して 決定した。投与方法はホルモン剤では，medroxyprogesterone acetate (以下 MPA) : $10 \mathrm{mg} / \mathrm{Kg}$ ，連 日筋注投与, tamoxifen (以下 TAM) $: 0.4 \mathrm{mg} / \mathrm{Kg}$, 連日経口投与, 卵巣剔除 (以下卵剔) : DMBA 投与 1 週後に両側卵剔とし, 免疫賦活剂では, OK 432 : $0.1 \mathrm{~K} \cdot \mathrm{E} / \mathrm{Kg}$, 週 1 回腹腔内投与, PSK : $60 \mathrm{mg} / \mathrm{Kg}$, 連日経口投与とした. DMBA 投与後 15 週まで, 毎週 ラット各頭について乳腺腫瘍（充実性）の発生の有 無をしらべた.

結果

まず未治療 control 群であるが，図 1 に示した如

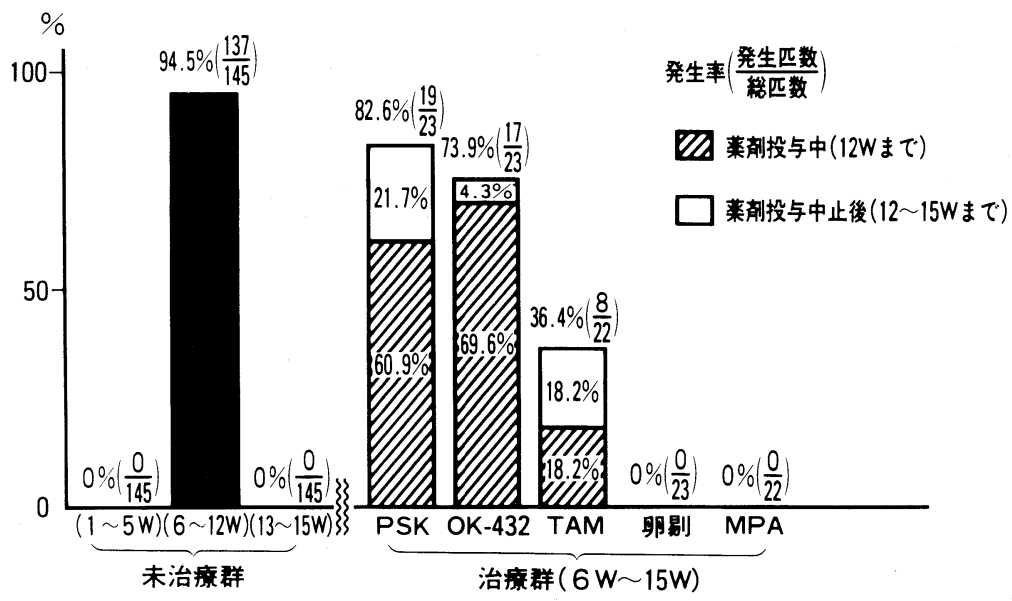

図 1 各群の乳腺腫瘍発生率

䚺論文別刷請求先 $\bar{T} 371$ 前橋市昭和町三丁目39-22

群馬大学医学部第二外科学教室

飯 野 佑一 
く乳腺腫場の発生率は 1 ～週で $0 \%(0 / 145), 6$ 〜 12 週で94.5\%（137/145)，13〜15週で 0\%（0/ 145)であり，15週の全経過中乳腺腫瘍の発生率は 6 〜12週に限定していた。したがって治療群の各薬剤 投与期間は乳腺腫場発生過程と一致していることが わかる。

次に各治療群における乳腺腫瘍の発生率を薬剤投 与期間の 12 週と薬剂投与中止期間を含む 15 週とで観 察した (図 1).まず治療各群を control 群と比較し てみると, PSK 群では12週60.9\% (14/23)，15週82. $6 \%(19 / 23)$ の腫場発生率であり, control 群に比し てそれぞれ有意に発生率が低下した（ $\mathrm{P}<0.001 ，$ $\mathrm{P}<0.05)$. OK 432群でも 12 週69.6\% (16/23), 15 週73.9\% (17/23) であり, 発生率が有意に低下した $(\mathrm{P}<0.001 ， \mathrm{P}<0.001) . \mathrm{TAM}$ 群では 12 週 $18.2 \%$ $(4 / 22), 15$ 週36.4\% (8/22) とさらに発生率が低下 した $(\mathrm{P}<0.0001 ， \mathrm{P}<0.0001)$ 。また卵剔群抢よび MPA 群では15週までに乳腺腫瘍の発生は認められ なかった。したがって乳腺腫瘍の発生過程に一致し たホルモン剂および免疫賦活剤の投与は腫瘍の発生 を抑制するものと思われた。ここで治療群間の腫瘍 発生率を比較してみると, TAM 群は OK-432群, PSK 群に対して12週および15週とも有意に発生率 が低下した(12週：P<0.0025, P <0.001，15週： $\mathrm{P}<0.001, \mathrm{P}<0.01)$. しかしながら $\mathrm{OK} 432$ 群と PSK 群との間に有意差は認められなかった。

次に DMBA 乳腺腫瘍の初発時期 (DMBA 投与 後)について各群で比較検討した(表 1). control 群

表 1 乳腺腫瘍初発時期 (DMBA投与後)

\begin{tabular}{l|c}
\hline Control & $7.9 \pm 1.7$ \\
OK432 & $8.5 \pm 1.7$ \\
PSK & $9.6 \pm 2.7$ \\
TAM & $12.1 \pm 2.9$ \\
卵 剔 & - \\
MPA & - \\
\hline & Mean \pm SD (Weeks)
\end{tabular}

の初発時期は7.9土1.7週であり,ついで OK432群8.

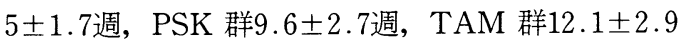
週の順に延長した。この中で PSK 群, TAM 群は control 群に比して有意差を示した $(\mathrm{P}<0.02, \mathrm{P}<$ 0.005)。また OK432群と PSK 群には有意差が認め られなかったが, TAM 群は OK432群, PSK 群そ
れぞれに対して有意差を示した $(\mathrm{P}<0.001, \mathrm{P}<0$. 05).

\section{考察}

最近乳癌の治療は著しい進歩をとげている。この 中にあってホルモン療法 ${ }^{1)}$, 免疫療法 ${ }^{2 \sim 4)} も$ その成果 をあげている，従来進行癌に対する治療剤として用 いられてきた薬剤も, 最近では発生予防のための補 助療法剂(5)としても重要視されるようになってきて いる. 他方これら薬剤の癌治療のための効果と発癌 過程に及ぼす効果とは必ずしも一致するものではな く,またその関連についての検討は十分ではない。 そこで今回ホルモン療法剤と免疫賦活剂の DMBA 乳腺腫瘍発生抑制作用について検討してみた。免疫 賦活剤の発癌抑制作用についての報告6,7) およびい わゆるホルモン療法剤のそれ ${ }^{8,9)}$ は比較的多く認め られるが，双方の発癌抑制作用についての系統的な 実験報告は著者らのしらべた限りではみられない。 免疫賦活剤の発癌抑制に関しては, 中野らによれ ば6), PS-K添加食品群は control 群に比して DMBA 乳腺腫瘍の発生が有意に低下し, 腫瘍発生 時期も有意に延長したという.

次にホルモン療法剤の発癌抑制に関しては長澤に よれば8)， 7 週齢の発情前期の夕刻にはラット乳腺 の DNA 合成能は血中プロラクチンレベルとともに きわめて高く, この時期にプロラクチンを投与すれ ば DMBA 乳癌の発癌性は高くなり, 抗プロラクチ ン剤 CB-154を投与すると発癌性は抑えられると し, プロラクチン $\rightarrow$ 乳腺の DNA 合成能 $\rightarrow$ 乳癌発生 の関係を強調している。 また吉田9) は, ラットにお いて女性ホルモンの豊富な状態では, 乳癌は容易に 発生し, 女性ホルモンの貧困な状態では乳癌の発生 は著しく抑制されるが，DMBA の頻回投与のよう な長期間の大量な発癌刺激はこのような状態におい ても高頻度に乳癌を誘発しうると報告している. 今 回のわれわれの成績もホルモン剂投与群および免疫 賦活剂投与群は control 群に比して有意に DMBA 乳腺腫瘍の発生率が低下し, 乳腺腫瘍発生時期も延 長するという結果であった. また今回の薬荗投与量 は臨床投与量から投算したものであり, 動物害験に は少ない投与量群もありうるため各群間の比較をす ることは適当ではないと思われるが, 今回の投与量 では腫瘍発生抑制作用は免疫賦活剤よりもホルモン 剂の方に強く認められた。これは用いた実験系がホ 
ルモン依存性の強い DMBA 乳腺腫瘍であった為か とも思われる. 今後これら薬剤によりもたらされる 動物個体の免疫能やホルモン代謝の変動を知ること も重要と考える.

\section{結語}

ホルモン療法剤および免疫賦活剤の投与により， DMBA 乳腺腫瘍の発生率が control 群に比して有 意に低下し, 腫瘍初発時期も延長した。

\section{文献}

1）泉雄 勝,飯野佑一：乳癌のホルモン療法。ホ と臨床, $29: 439-445,1981$.

2) 河村秀敏：化学療法と免疫療法の併用で好転 した再発乳癌の 1 症例. 薬理と治療, $8: 2563-$ 2568, 1980.

3) 沢井清司： 進行・再発乳癌に対する ChemoEndocrine-Immuno Therapy (adriamycin, tamoxifen，OK-432）の治療成績. 日本癌治療 学会誌, $19 ： 1315-1320,1984$.
4) Hortobagyi, G. N., et al: Combination chemoimmunotherapy of metastatic breast cancer with 5 -fluorouracil, adriamycin, cyclophosphamide, and BCG. Cancer, 44 : $1955-1962,1979$.

5）野村雍夫：乳癌一外科的立場から一. 癌と化 学療法, 11:981-988, 1984.

6）中野陽典・他：抗腫瘍性蛋白糖 PS-K 添加 食の DMBA 乳腺腫瘍発生に対する影響. 医学 のあゆみ，99：11-12，1976。

7）水口滋之・他：ラット ENNG 発癌に及ぼす各 種免疫賦活物質の影響. 医学のあゆみ, 133 : 321-322, 1985.

8）長澤 弘： 内分泌依存性癌発生におけるホル モンの役割。日本内分泌学会雑誌，58. 306, 1982.

9）吉田浩己：乳癌の発生とホルモン環境. 癌の 臨床別集/乳癌-内分泌療法, 篠原出版, 東京, 1981, 59-73. 


\title{
THE EFFECTS OF VARIOUS HORMONES AND IMMUNOPOTENTIATORS ON DMBA-INDUCED CARCINOGENESIS IN SD RAT MAMMARY GLANDS
}

\section{YUICHI IINO, HIROSHI ISHIKAWA, MASAO YOSHIDA, MASARU IZUO AND HIROO TAKIKAWA*}

\author{
Second Departrent of Surgery, \\ Gunma University School of Medicine, Maebashi, 371, Japan. \\ (Director: Prof. Masaru Izuo) \\ *Department of Pharmateutical Chemistry, \\ Institute of Endocrinology, Gunma University, Maebashi, Japan.
}

The effects of various hormones and immunopotentiators on 7, 12-dimethylbenz 〔a〕 anthracene (DMBA)-induced carcinogenesis in the SD rat mammary glands were studied. Female SD rats aged six weeks were given $20 \mathrm{mg}$ of DMBA by gastric intubation.

A week after the DMBA administration, these rats were divided into six groups: tamoxifen (TAM) $(0.4 \mathrm{mg} / \mathrm{kg} /$ day, PS), medroxyprogesterone acetate (MPA) $(10 \mathrm{mg} / \mathrm{kg} / \mathrm{day}, \mathrm{IM})$, oophorectomy (Ovex) (a week after DMBA administration), OK-432 (0.1K•E/ $/ \mathrm{kg} /$ week, IP), PSK (60mg/ $\mathrm{kg} /$ day, PS) and the control group. Each group had been administered the respective drug between first and 12th weeks, and the presence of mammary tumors had been investigated every week up to the 15th week. Mammary tumors in the control group appeared only between the sixth and 12th weeks.

The period of administration in the therapeutic groups agreed with that of the appearance of mammary tumors in the control.

The occurrence of mammary tumors at the 12th and 15th weeks in each group was $94.5 \%$ in control, $60.9 \%$ and $82.6 \%$ in PSK, $69.6 \%$ and $73.9 \%$ in $\mathrm{OK}-432,18.2 \%$ and $36,4 \%$ in TAM, $0 \%$ in Ovex and $0 \%$ in MPA.

The first appearance periods of DMBA tumors were $7.9 \pm 1.7$ weeks in control, $8.5 \pm 1.7$ weeks in OK-432, 9.6 \pm 2.7 weeks in PSK and $12.1 \pm 2.9$ weeks in TAM.

Compared with the control group, those receiving hormones and immunopotentiators showed a significantly lower rate in the appearance of DMBA tumors and a delay in the first appearance period of DMBA tumors.

Key words: Hormones, Immumopotentiators, DMBA-induced carcinogenesis, SD rat mammary glands. 